\title{
ARTIKEL \\ PENGARUH PENGGUNAAN MEDIA FILM BINGKAI TERHADAP KEMAMPUAN MENULIS PUISI OLEH SISWA KELAS VIII SMP NEGERI 1 SILIMA PUNGGA PUNGGA TAHUN PEMBELAJARAN 2016/2017
}

Oleh

James Haposan Marpaung

NIM 2133111036

Telah Diverifikasi dan Dinyatakan Memenuhi Syarat untuk Diunggah pada Jurnal Online

Editor,

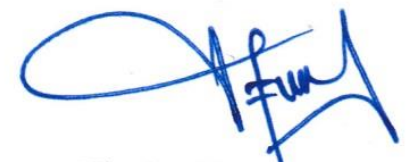

Fitriani Lubis, S.Pd., M.Pd. NIP 197708312008122001
Dosen Pembimbing Skripsi,

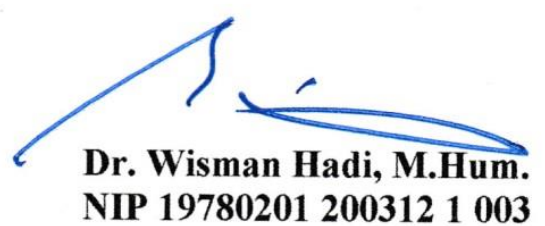

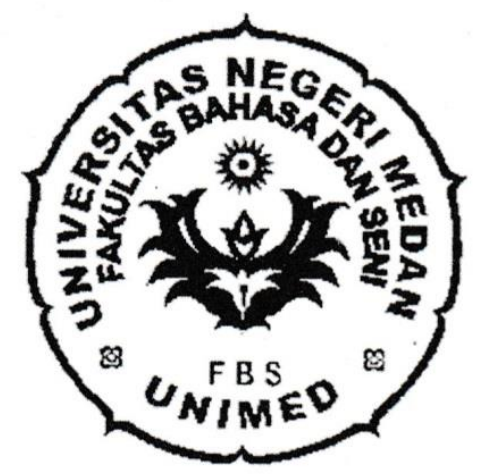

JURUSAN BAHASA DAN SASTRA INDONESIA

FAKULTAS BAHASA DAN SENI UNIVERSITAS NEGERI MEDAN 


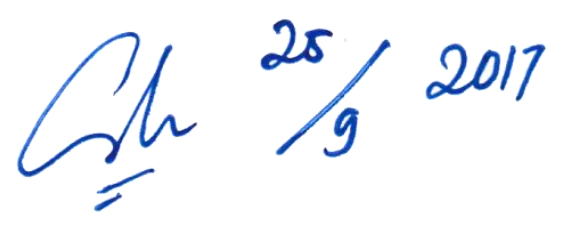

\title{
PENGARUH PENGGUNAAN MEDIA FILM BINGKAI \\ TERHADAP KEMAMPUAN MENULIS PUISI \\ OLEH SISWA KELAS VIII SMP NEGERI 1 \\ SILIMA PUNGGA PUNGGA TAHUN \\ PEMBELAJARAN 2016/2017
}

\author{
James Haposan Marpaung (jamespoeng@yahoo.co.id) \\ Dr. Wisman Hadi, M.Hum.
}

\begin{abstract}
Abstrak
Secara umum tujuan penelitian ini adalah untuk mengetahui pengaruh penggunaan media film bingkai terhadap kemampuan menulis puisi oleh siswa kelas VIII SMP Negeri 1 Silima Pungga Pungga Tahun Pembelajaran 2016/2017. Metode yang digunakan adalah metode eksperimen one-grup pre-test post-test design. Data diperoleh melalui wawancara, observasi, dan tes (tes uraian), sedang untuk pengujian data adalah uji normalitas, uji homogenitas, dan uji hipotesis. Penelitian ini akan mengetahui (1) kemampuan hasil belajar siswa sebelum menggunakan media film bingkai terhadap kemampuan menulis puisi oleh siswa kelas VIII SMP Negeri 1 Silima Pungga Pungga; (2) kemampuan hasil belajar siswa setelah menggunakan media film bingkai terhadap kemampuan menulis puisi oleh siswa kelas VIII SMP Negeri 1 Silima Pungga Pungga; (3) pengaruh penggunaan media film bingkai terhadap kemampuan menulis puisi oleh siswa kelas VIII SMP Negeri 1 Silima Pungga Pungga. Rata-rata pencapaian hasil belajar siswa sebelum menggunakan media film bingkai adalah 64,5, termasuk kategori cukup. Setelah menggunakan media, hasil belajar siswa menjadi 84,66, termasuk kategori baik.
\end{abstract}

Kata kunci: media film bingkai, menulis puisi, hasil belajar.

\section{PENDAHULUAN}

Pengajaran Bahasa Indonesia mencakup empat keterampilan, yaitu keterampilan menyimak, keterampilan berbicara, keterampilan membaca, dan keterampilan menulis. Keterampilan menulis merupakan salah satu keterampilan berbahasa yang dianggap menjadi pokok bahasan yang paling sulit disampaikan oleh guru untuk diterapkan oleh siswa. Hal ini disebabkan oleh sulitnya siswa mengembangkan gagasan mereka dan menuangkannya dalam bahasa tulis. Kagiatan menulis termasuk ke dalam kegiatan yang produktif dan ekspresif. Ketika menulis, seorang penulis harus terampil memanfaatkan pilihan kata, struktur bahasa, penguasaan kosa kata agar tulisan yang dihasilkan jelas dan efektif. 
Dalam Kurikulum Tingkat Satuan Pendidikan (KTSP), materi pembelajaran Bahasa dan Sastra Indonesia di SMP atau MTs terdiri atas dua jenis keterampilan, yaitu keterampilan berbahasa dan keterampilan bersastra. Kegiatan menulis puisi merupakan salah satu kompetensi dasar dalam Kurikulum Tingkat satuan Pendidikan (KTSP). Standar Kompetensi menulis puisi pada Silabus Bahasa Indonesia kelas VIII SMP adalah mengungkapkan pikiran, dan perasaan dalam puisi bebas, sedangkan kompetensi dasarnya adalah menulis puisi bebas dengan menggunakan pilihan kata yang sesuai (KD 16. 1).

Kemampuan siswa menulis puisi berdasarkan observasi di lapangan masih tergolong rendah. Siswa mengalami kesulitan menggunakan pilih kata yang tepat saat menulis puisi. Penyebab utamanya adalah adalah kurangnya minat dan motivasi siswa untuk menulis puisi. Faktor lainnya adalah kurangnya pembendaharaan kata yang dimiliki oleh siswa tersebut sehingga ketika mereka diminta menulis puisi mereka justru merasa bingung.

Di tempat yang berbeda, hasil wawacara yang dilakukan dengan guru Bidang Studi Bahasa Indonesia kelas VIII SMP Negeri 1 Silima Pungga Pungga, Poltak Sihombing, S. Pd. menunjukkan bahwa kemampuan menulis puisi siswa di sekolah tersebut masih tergolong sangat rendah. Hasil observasi menunjukkan bahwa masih banyaknya siswa yang memperoleh nilai dibawah standar (KKM) yang telah ditentukan. Selain dikarenakan kurangnya pembendaharaan kata dan kurangnya latihan menulis puisi oleh siswa itu sendiri, penyebab lain rendahnya kemampuan menulis puisi mereka tersebut adalah proses pembelajaran yang dilakukan oleh guru pada materi menulis puisi tidak inovatif sehingga siswa merasa bosan dan tidak tertarik untuk terlibat aktif dalam proses pembelajaran menulis puisi. Siswa kurang termotivasi untuk terlibat secara aktif dalam pembelajaran karena guru hanya berceramah di depan kelas dan tidak menggunakan media sebagai alat bantu pembelajaran.

Cara yang dapat dilakukan untuk merangsang motivasi dan keterampilan siswa dalam menulis puisi adalah dengan menggunakan media pembelajaran. Media mengandung pesan sebagai perangsang belajar dan dapat menumbuhkan motivasi belajar sehingga siswa menjadi tidak bosan dalam meraih tujuan-tujuan belajar. Hamalik (dalam Arsyad, 2011:25) berpendapat bahwa pemakaian media pembelajaran dalam proses belajar mengajar dapat membangkitkan keinginan dan minat yang baru, membangkitkan motivasi, dan rangsangan kegiatan belajar, dan bahkan membawa pengaruh-pengaruh psikologis terhadap siswa. Sependapat dengan hal tersebut, Haryoko (2009) mengatakan bahwa salah satu media yang digunakan dalam pembelajaran dan diyakini dapat meningkatkan animo mahasiswa dalam mengikuti perkuliahan adalah media audio-visual (termasuk film bingkai). Pendapat tersebut 
didukung oleh penelitian yang dilakukan oleh Napitupulu (2016). Napitupulu mengatakan bahwa media film bingkai sangat efektif untuk meningkatkan kemampuan menulis cerita pendek.

Berdasarkan latar belakang tersebut di atas maka dapat dirumuskan masalah : (1)Bagaimana kemampuan menulis puisi oleh siswa kelas VIII SMP Negeri 1 Silima Pungga Pungga Tahun Pembelajaran 2016/2017 sebelum menggunakan media film bingkai? (2) Bagaimana kemampuan menulis puisi oleh siswa kelas VIII SMP Negeri 1 Silima Pungga Pungga Tahun Pembelajaran 2016/2017 setelah menggunakan media film bingkai? (3) Apakah media film bingkai berpengaruh terhadap kemampuan menulis puisi oleh siswa kelas VIII SMP Negeri 1 Silima Pungga Pungga Tahun Pembelajaran 2016/2017? Penelitian ini diharapkan dapat membantu guru dalam meningkatkan pembelajaran menulis puisi serta membantu guru dalam menentukan media yang kreatif sehingga dapat menunjang keberhasilan proses belajar mengajar, khusunya menulis puisi.

\section{METODE PENELITIAN}

Penelitian ini dilakukan di SMP Negeri 1 Silima Pungga Pungga, Kabupaten Dairi. Dilaksanakan pasa semester genap tahun pembelajaran 2016/2017. Populasi dalam penelitian ini adalah seluruh siswa kelas VIII di SMP Negeri 1 Silima Pungga Pungga yang berjumlah 206 orang siswa. Seluruh populasi didistribusikan ke dalam tujuh kelas. Dari populasi tersebut (dari kelas kelas VIII-1 sampai kelas VIII-7), ditetapkan sampel penelitian yaitu kelas VIII-2 yang terdiri dari 30 orang siswa. Pengambilan sampel yang digunakan adalah secara acak kelas (random sampling).

Variabel yang diungkapkan dalam penelitian ini adalah media film bingkai (variabel $\mathrm{X}$ ) dan kemampuan menulis puisi (variabel Y). Selanjutya desain penelitian yang diterapkan dalam penelitian ini adalah one group pre-test and post-test. Instrumen yang digunakan adalah siswa ditugaskan menulis puisi (uraian test). Tes uraian akan diberikan pada sebelum dan sesudah menggunakan media, sehingga akan terlihat pengaruh penggunaan media film bingkai tersebut.

Data yang diperolah akan dianalisis dengan menggunakan teknik statistik deskriptif dan statistik inferensial. Teknik statistik deskriptif digunakan untuk mendeskripsikan skor siswa sebelum dan sesudah diberi perlakuan. Sedangkan statistik inferensial digunakan untuk menguji hipotesis (uji t). Sebelum uji t, terlebih dahulu diadakan uji persyaratan analisis yaitu uji normalitas dan uji homogenitas varians. 


\section{HASIL PENELITIAN DAN PEMBAHASAN HASIL PENELITIAN}

\section{Hasil Penelitian}

Langkah awal sebelum diberi perlakuan dalam menulis puisi dilakukan terlebih dahulu pratindakan pembelajaran untuk mengetahui kemampuan awal siswa kelas VIII-2 SMP Negeri 1 Silima Pungga Pungga. Hasil menulis puisi pada tahap pratindakan (pre-test) menunjukkan kemampuan siswa tergolong rendah dengan perolehan nilai terendah 55 dan nilai tertinggi 75. Rata-rata dari akumulasi nilai keseluruhan pada tahap pratindakan sebesar 64,5. Hasil menulis puisi setelah diberikan perlakuan menunjukkan peningkatan rata-rata perolehan nilai menjadi 84,66 tergolongan baik. Rentan perolehan nilai setelah perlakuan (post-test) adalah 75-100.

Tabel 1. Skor Hasil Menulis Puisi Siswa Pada Tahap Pre-test dan Post test.

\begin{tabular}{|c|c|c|c|}
\hline No & Nama Siswa & Nilai pre-test & Nilai post-test \\
\hline 1 & Angel Marta Siregar & 75 & 100 \\
\hline 2 & Arianto Tambunan & 60 & 75 \\
\hline 3 & Benni Sibuea & 65 & 90 \\
\hline 4 & Brilian Y. Panjaitan & 55 & 75 \\
\hline 5 & Daniel Purba & 70 & 90 \\
\hline 6 & Elisabeth Naibaho & 65 & 80 \\
\hline 7 & Elsa Sihombing & 70 & 90 \\
\hline 8 & Endang Butar-butar & 70 & 85 \\
\hline 9 & Gabe S. Marpaung & 60 & 80 \\
\hline 10 & Govindo Sirait & 70 & 95 \\
\hline 11 & Harri Sinaga & 60 & 75 \\
\hline 12 & Hengki S. Purba & 65 & 75 \\
\hline 13 & Ihut Rotua Manalu & 60 & 85 \\
\hline
\end{tabular}




\begin{tabular}{|c|c|c|c|}
\hline 14 & Laila H. Siregar & 70 & 95 \\
\hline 15 & Lusi Manalu & 70 & 80 \\
\hline 16 & $\begin{array}{l}\text { Markable Abram } \\
\text { Simangungsong }\end{array}$ & 55 & 75 \\
\hline 17 & Marta Sibarani & 65 & 90 \\
\hline 18 & Mesra Sinambela & 60 & 80 \\
\hline 19 & Natanael Manurung & 60 & 85 \\
\hline 20 & Nikson Panjaitan & 55 & 75 \\
\hline 21 & Novenri Manurung & 55 & 75 \\
\hline 22 & Ratna Situmorang & 55 & 75 \\
\hline 23 & Ridwan Manalu & 65 & 90 \\
\hline 24 & Ruth Shintya Sinurat & 75 & 95 \\
\hline 25 & Sartika Sihombing & 70 & 80 \\
\hline 26 & Siska Sirait & 65 & 95 \\
\hline 27 & Taripar Doloksaribu & 65 & 90 \\
\hline 28 & Torang T. Sinaga & 70 & 90 \\
\hline 29 & Tulus Siagian & 75 & 95 \\
\hline 30 & Wawan Panjaitan & 60 & 80 \\
\hline & Jumlah & 1935 & 2540 \\
\hline & Rata-rata & 64,5 & 84,66 \\
\hline
\end{tabular}

Dari tabel sebelum dan sesudah penggunaan media di atas dapat dilihat nilai masingmasing siswa. Kemampuan seluruh siswa dalam menulis puisi setelah menggunakan media film bingkai meningkat. Kenaikan juga terjadi pada tahap sebelum penggunaan media film 
bingkai yang berkategori cukup dengan nilai rata-rata 64,5 dibandingkan dengan tahap setelah penggunaan media film bingkai yang berkategori baik dengan nilai rata-rata 84,66.

Setelah data dianalisis dengan menggunakan statistik deskriptif, selanjutnya adalah menganalisis data dengan statistik inferensial yaitu dengan melakukan uji t. Sebelum dilakukan uji t, terlebih dulu dilakukan uji normalitas dan uji homogenitas. Tujuan dilakukannya uji normalitas adalah untuk mengetahui apakah populasi pada saat pre-test maupun post-test berdistribusi normal atau tidak. Dengan ketentuan $\mathrm{L}_{\text {hitung }}<\mathrm{L}_{\text {tabel. }}$. Uji normalitas pada pre-test dan post-test dapat dilihat pada tabel di bawah ini.

Tabel 2. Uji Normalitas Data Kelompok Sebelum Menggunakan Media Film Bingkai

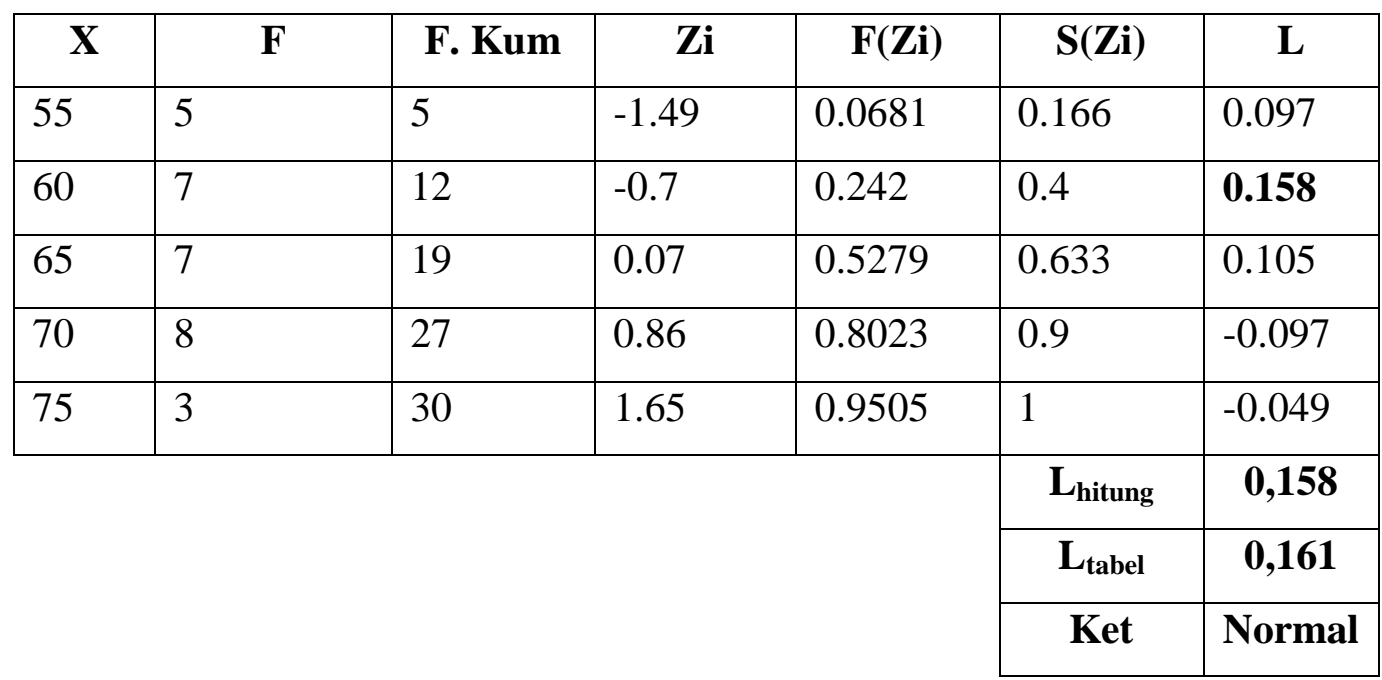

Berdasarkan tabel di atas, maka dapat diketahui $\mathrm{L}_{\text {hitung }}$ sebesar 0,158 dengan menggunakan $\alpha=0,05$, dan $\mathrm{N}=30$, serta nilai kritis melalui uji Liliefors diperoleh $\mathrm{L}_{\text {tabel }}$ sebesar 0,161. Dengan demikian, $\mathrm{L}_{\text {hitung }}<\mathrm{L}_{\text {tabel }}$ yaitu $0,158<0,161$ dan hal ini membuktikan bahwa data pre-test berdistribusi normal.

Tabel 3. Uji Normalitas Data Kelompok Sesudah Menggunakan Media Film Bingkai

\begin{tabular}{|c|c|c|c|c|c|c|}
\hline $\mathbf{Y}$ & $\mathbf{F}$ & $\mathbf{F}, \mathbf{K u m}$ & $\mathbf{Z i}$ & $\mathbf{F}(\mathbf{Z i})$ & $\mathbf{S}(\mathbf{Z i})$ & $\mathbf{L}$ \\
\hline 75 & 7 & 7 & $-1,2$ & 0,1151 & 0,233 & 0,118 \\
\hline 80 & 6 & 13 & $-0,57$ & 0,2912 & 0,433 & $\mathbf{0 , 1 4 2}$ \\
\hline 85 & 2 & 15 & 0,04 & 0,516 & 0,5 & 0,016 \\
\hline
\end{tabular}




\begin{tabular}{|c|c|c|c|c|c|c|}
\hline 90 & 9 & 24 & 0,66 & 0,7454 & 0,8 & 0,0546 \\
\hline 95 & 5 & 29 & 1,28 & 0,8997 & 0,966 & 0,066 \\
\hline 100 & 1 & 30 & 1,9 & 0,9713 & 1 & 0,029 \\
\hline \multicolumn{5}{|c}{} & $\mathbf{L}_{\text {hitung }}$ & $\mathbf{0 , 1 4 2}$ \\
\cline { 5 - 6 } & & $\mathbf{L}_{\text {tabel }}$ & $\mathbf{0 , 1 6 1}$ \\
\cline { 5 - 6 } & & Ket & Normal \\
\hline
\end{tabular}

Berdasarkan tabel di atas, maka dapat diketahui $\mathrm{L}_{\text {hitung }}$ sebesar 0,142 dengan menggunakan $\alpha=0,05$, dan $\mathrm{N}=32$, serta nilai kritis melalui uji Liliefors diperoleh $\mathrm{L}_{\text {tabel }}$ sebesar 0,161. Dengan demikian, $\mathrm{L}_{\text {hitung }}<\mathrm{L}_{\text {tabel }}$ yaitu $0,142<0,161$ dan hal ini membuktikan bahwa data post-test berdistribusi normal.

Selanjutnya adalah untuk menguji apakah varians kedua variabel tersebut homogen atau heterogen, maka akan dilakukan uji homogen, dengan menggunakan formula sebagai berikut:

$$
\mathrm{F}=\frac{\text { var iansterbesar }}{\text { var iansterkecil }}
$$

Kriteria pengujian adalah $\mathrm{H}_{\mathrm{o}}$ diterima jika $\mathrm{F}_{\text {hitung }}<\mathrm{F}_{\text {tabel }}$ diambil dk pembilang adalah $\mathrm{dk}$ varians terbesar dan $\mathrm{dk}$ penyebut adalah $\mathrm{dk}$ varians terkeci. Maka diperoleh $\mathrm{F}_{\mathrm{hitung}}=1,26$ dengan $\mathrm{dk}$ pembilang dan penyebut 30 dari tabel distribusi $\mathrm{F}$ untuk $\alpha=0,05$ diperoleh $\mathrm{F}_{\text {tabel }}$ untuk dk pembilang dan penyebut 30 yaitu $F_{\text {tabel }}=4,20$. Jadi, $F_{\text {hitung }}<F_{\text {tabel }}$ yakni 1,26 $<4,20$. Hal ini membuktikan bahwa sampel Ho yang menyatakan bahwa varians kedua variabel tersebut homogen.

Setelah dilakukan pengujian persyaratan analisis, dan ternyata distribusi datanya normal dan homogen, maka dilanjutkan dengan melakukan uji t, dengan membandingkan gain skor antara pre-test dengan post-test.

$$
\begin{aligned}
& t_{o}=\frac{M_{1}-M_{2}}{S E_{M_{1}-M_{2}}} \\
& \quad \begin{array}{r}
S E_{M 1-M 2}=\sqrt{\left(S E_{M 1}\right)^{2}+\left(S E_{M 2}\right)^{2}} \\
=1,83
\end{array} \\
& \mathrm{M}_{1}=84,84, \text { sedangkan } \mathrm{M}_{2}=64,5
\end{aligned}
$$

Maka,

$$
\mathrm{t}_{\mathrm{o}}=11,21
$$


Diperoleh $t_{0}=11,21$, kemudian dikonsultasikan dengan tabel $\mathrm{t}$ taraf signifikan $5 \%$ dengan $\mathrm{df}=\mathrm{N}-1=30-1=29$ diperoleh taraf signifikan $5 \%=2,04$. Karena $\mathrm{t}_{0}$ diperoleh lebih besar dari $t_{\text {tabel }}$ yaitu 11,21 > 2,04, maka hipotesis penelitian yang mengatakan bahwa ada pengaruh yang signifikan dari penerapan media film bingkai terhadap kemampuan menulis puisi siswa kelas VIII SMP Negeri 1 Silima Pungga Pungga Tahun Pembelajaran 2016/2017 dapat diterima.

Setelah melakukan analisis data, penggunaan media film bingkai dalam kegiatan menulis puisi oleh siswa kelas VIII SMP Negeri 1 Silima Pungga Pungga ternyata berpengaruh positif. Hal ini terbukti dari hasil penelitian yang menunjukkan nilai siswa dalam menulis cerita pendek mengalami peningkatan. Nilai rata-rata siswa setelah menggunakan media film bingkai yaitu sebesar 84,66 termasuk kategori baik. Hal ini membuktikan adanya peningkatan yang signifikan dari tes awal (Pre-Test).

\section{Pembahasan Hasil Penelitian}

a. Kemampuan Menulis Puisi Sebelum Menggunakan Media Film Bingkai oleh Siswa Kelas VIII SMP Negeri 1 Silima Pungga Pungga Tahun Pembelajaran 2016/2017

Hasil menulis puisi oleh siswa kelas VIII SMP Negeri 1 Silima Pungga Pungga Tahun Pembelajaran 2016/2017 sebelum menggunakan media film bingkai, termasuk dalam kategori cukup dengan nilai rata-rata 64,5. Kemampuan ini berada di bawah KKM yang sudah ditetapkan SMP Negeri 1 Silima Pungga Pungga dalam menulis puisi yaitu sebesar 75 .

Sebagaimana disajikan pada hasil penelitian, bahwasannya hal ini sesuai dengan penelitian yang dilakukan Widodo dkk. (2013).

Dari kegiatan pratindakan diperoleh hasil bahwa hanya 4 siswa yang tuntas dalam pembelajaran menulis. Nilai rata-rata yang dicapai kelas X-A di akhir pembelajaran belum memenuhi nilai KKM. Nilai rata-rata kelas tersebut ialah 67,66 . Nilai yang paling rendah, yang didapat oleh siswa ialah 60, pada 5 siswa. Nilai antara 61-65 didapat 9 siswa. 12 siswa mendapat nilai akhir antara 66-70. Nilai 71-74 didapatkan 2 siswa. Di smaping itu, hanya 4 siswa mendapat nilai sama atau di atas KKM, yakni 75. Berdasarkan hasil pratindakan tersebut, dapat dikatakan, dapat dikatakan bahwa keterampilan menulis puisi siswa siswa kelas X-A SMAN 1 Gemolong belum sesuai dengan yang diharapkan.

Selain dikarenakan kurangnya pembendaharaan kata dan kurangnya latihan menulis puisi oleh siswa itu sendiri, penyebab lain rendahnya kemampuan menulis puisi mereka tersebut adalah proses pembelajaran yang dilakukan oleh guru pada materi menulis puisi tidak inovatif sehingga siswa merasa bosan dan tidak tertarik untuk terlibat aktif dalam proses pembelajaran menulis puisi. Siswa kurang termotivasi untuk terlibat secara aktif dalam pembelajaran karena guru hanya berceramah di depan kelas dan tidak menggunakan media sebagai alat bantu pembelajaran. Pada tahap sebelum penerapan media film bingkai ini siswa berlatih untuk meningkatkan kemampuan menulisnya hanya dengan menuliskan apa yang mereka tahu saja tanpa diberikan arahan yang menarik agar siswa berpikir secara logis dan sistematis. 


\section{b. Kemampuan Menulis Puisi Setelah Menggunakan Media Film Bingkai oleh Siswa Kelas VIII SMP Negeri 1 Silima Pungga Pungga Tahun Pembelajaran 2016/2017}

Setelah mengerjakan post-test dan melakukan analisis data, penggunaan media film bingkai dalam kegiatan menulis puisi oleh siswa kelas VIII SMP Negeri 1 Silima Pungga Pungga ternyata berpengaruh positif. Hal ini terbukti dari hasil penelitian yang menunjukkan nilai siswa dalam menulis cerita pendek mengalami peningkatan. Peningkatan nilai yang diperoleh siswa disebabkan oleh media film bingkai. Dilihat dari hasil nilai rata-rata siswa pada post-test hanya mencapai 64,5 dengan kategori cukup. Sedangkan hasil post-test nilai rata-rata menjadi 84,66 termasuk kategori baik. Hal ini membuktikan adanya peningkatan yang signifikan dari tes awal (Pre-Test).

Meningkatnya kemampuan siswa dalam menulis puisi juga didukung dengan hasil penelitian yang dilakukan oleh Hamalik (dalam Arsyad, 2011:25), yang berpendapat bahwa pemakaian media pembelajaran dalam proses belajar mengajar dapat membangkitkan keinginan dan minat yang baru, membangkitkan motivasi, dan rangsangan kegiatan belajar, dan bahkan membawa pengaruh-pengaruh psikologis terhadap siswa. Sependapat dengan hal tersebut, Haryoko (2009) mengatakan bahwa salah satu media yang digunakan dalam pembelajaran dan diyakini dapat meningkatkan animo mahasiswa dalam mengikuti perkuliahan adalah media audio-visual (termasuk film bingkai).

Dengan demikian hal ini jelas bahwa media film bingkai ini adalah media pembelajaran yang sangat efektif yang dapat digunakan guru untuk merangsang dan mengembangkan kemampuan siswa dalam menulis puisi. Dengan penggunaan ini dalam proses pembelajaran, guru dapat meningkatkan hasil belajar siswa. Hal tersebut terbukti dari hasil penelitian dan data yang diperoleh.

\section{c. Pengaruh Penggunaan Media Film Bingkai Terhadap Kemampuan Menulis Puisi oleh Siswa Kelas VIII SMP Negeri 1 Silima Pungga Pungga Tahun Pembelajaran 2016/2017}

Sebagaimana disajikan pada hasil penelitian yang menunjukan nilai rata-rata untuk kemampuan menulis siswa pada tahap sebelum penggunaan media tergolong pada kategori cukup dengan nilai rata-rata 64,5 dibandingkan dengan tahap setelah penggunaan media yang berkategori baik dengan nilai rata-rata 84,66. Sehingga dari data tersebut dapat ditemukan bahwa media film bingkai berpengaruh dalam meningkatkan kemampuan menulis puisi.

Hal ini sesuai dengan hasil yang diharapkan yaitu meningkatkan hasil belajar siswa dan juga mencapai KKM yang sudah ditetapkan sekolah tersebut. Media film bingkai merupakan sebuah media pembelajaran yang pada pembelajarannya menggunakan media gambar yang dapat membantu siswa dalam mengembangkan ide dan gagasannya dalam belajar. Seperti yang dikatakan oleh Sadiman, dkk. (2003:30) dalam bukunya "Media Pendidikan" bahwa dengan menggunakan media film bingkai, berpikir siswa dirangsang dan dikembangkan secara besar.

Selain itu, media film bingkai juga dapat membangkitkan motivasi dan merangsang peserta didik untuk berani berperan aktif dalam belajar serta mampu menuliskan apa yang mereka lihat dari gambar dan kemudian menjadikannya sebuah puisi yang baik. 
Berdasarkan hasil penelitian, data sebelum dan sesudah menggunakan media film bingkai berdistribusi normal. Hal tersebut dapat dilihat dari uji normalitas data sebelum dan sesudah menggunakan media film bingkai. Dari data homogenitas juga terbukti bahwa sampel penelitian ini berasal dari populasi yang homogen. Kemudian pengujian hipotesis yang dilakukan diperoleh $\mathrm{t}_{\mathrm{o}}>\mathrm{t}_{\text {tabel}}$, yaitu 11,40 $>2,04$. Hal ini membuktikan bahwa hipotesis alternatif (Ha) diterima. Dengan demikian pengunaan media film bingkai ini berpengaruh secara signifikan terhadap kemampuan menulis puisi siswa kelas VIII SMP Negeri 1 Silima Pungga Pungga Tahun Pembelajaran 2016/2017.

\section{KESIMPULAN DAN SARAN}

\section{Kesimpulan}

Berdasarkan Hasil penelitian tentang pengaruh penggunaan media gambar peristiwa terhadap kemampuan menulis puisi oleh siswa kelas VIII SMP Negeri 1 Silima Pungga Pungga Tahun Pembelajaran 2016/2017dapat disimpulkan hal-hal berikut ini.

(1) Kemampuan siswa kelas VIII SMP Negeri 1 Silima Pungga Pungga Tahun Pembelajaran 2016/2017 dalam menulis puisi sebelum menggunakan media film bingkai tergolong cukup dengan nilai rata-rata yang diperoleh 64,5 termasuk dalam kategori cukup.

(2) Kemampuan siswa kelas VIII SMP Negeri 1 Silima Pungga Pungga Tahun Pembelajaran 2016/2017 dalam menulis puisi sesudah menggunakan media film bingkai tergolong baik dengan nilai rata-rata yang diperoleh 84,66 termasuk dalam kategori baik.

(3) Terdapat pengaruh media film bingkai terhadap kemampuan menulis puisi siswa VIII SMP Negeri 1 Silima Pungga Pungga Tahun Pembelajaran 2016/2017. Dapat dilihat dari hasil penelitian yang dilakukan yaitu hasil posttest serta hasil uji " $t$ " yaitu $\mathrm{L}_{\text {hitung }}<\mathrm{L}_{\text {tabel }}$ yaitu $(0,142<0,161)$, maka hipotesis nihil $(\mathrm{H} 0)$ ditolak dan hipotesis alternatif $(\mathrm{Ha})$ diterima.

\section{Saran}

Berdasarkan simpulan di atas, tindak lanjut penelitian ini perlu diungkapkan beberapa saran kepada peneliti dan guru Bahasa Indonesia seperti yang tertulis berikut ini.

(1) Kemampuan siswa dalam menulis puisi perlu ditingkatkan lagi. Hal tersebut tentunya membutuhkan media pembelajaran yang lebih efektif untuk digunakan dalam proses belajar mengajar di sekolah. Salah satu media pembelajaran yang dapat dijadikan alternatif adalah media film bingkai.

(2) Karena adanya peningkatan kemampuan siswa dalam menulis puisi setelah meggunakan media film bingkai, kepala sekolah sebaiknya mensosialisasikan penggunaan media film bingkai kepada guru-guru khususnya guru bidang studi Bahasa Indonesia. 
(3) Hasil penelitian tentang kemampuan menulis puisi diharapkan mampu menjadi pegangan bagi pelaku-pelaku pendidikan untuk mencari alternatif media pembelajaran yang lebih baik dengan cara melakukan penelitian lanjutan dengan media pembelajaran dan sistem mengajar yang lebih modern dan kreatif.

\section{DAFTAR PUSTAKA}

Akhadiah, Sabarti. 1997. Menulis. Jakarta: Departemen Pendidikan dan Kebudayaan.

Arikunto, Suharsimi. 2006. Prosedur Penelitian Suatu Pendekatan Praktis. Jakarta: Rineka Cipta

Arsyad, Azhar. 2011. Media Pembelajaran. Jakarta: Raja Wali Press.

Barus, Sanggup. 2010. Pembinaan Kompetensi Menulis. Medan: USU Press.

Daryanto. 2011. Media Pembelajaran. Bandung: Satu Nusa.

Haryoko, Sapto. 2009. Efektifitas Pemanfaatan Media Audio Visual Sebagai Alternatif Optimalisasi Model Pembelajaran. Jurnal Edukasi@Elektro Vol 5, No. 1, Maret 2009.

Kosasih, E. 2003. Ketatabahasaan dan Kesusastraan. Bandung : Yrama Widia.

Napitupulu, Putri Dewita. 2017. Pengaruh Media Film Bingkai Terhadap Kemampuan Menulis Cerita Pendek Oleh Siswa Kelas X SMA Swasta Bintang Timur 1 Balige Tahun Pembelajara 2015/2016. Skripsi Universitas Negeri Medan.

Sadiman, Arief S., dkk. 2010. Media Pendidikan: Pengertian, Pengembangan, dan Pemanfaatanny. Jakarta: Rajawali Pers.

Siswanto, Wahyudi. 2013. Pengantar Teori Sastra. Jakarta: Grasindo.

Sopandi. 2010. Memahami Puisi. Bandung: Perpustakaan Nasional

Sugiyono. 2010. Metode Penelitian Kuantitatif Kualitatif dan R\&D. Bnadung : Alfabeta 